\title{
Chapter 4 \\ Potential Impacts of Climate Change on Protected Habitats
}

\author{
Anca Sârbu, Georg Janauer, Ingolf Profft, Mitja Kaligarič, \\ and Mihai Doroftei
}

\subsection{Climate Change and the Protected Areas of Europe}

Climate change is recognised as a major global threat (Stern 2007), which will have significant impacts on many aspects of biological diversity in the near future (Campbell et al. 2009).

Unfortunately, climate change is happening on a day-to-day basis and will continue to affect biodiversity and, thus, induce biodiversity loss with negative effects for human well-being and natural systems (EEA 2010).

According to the existing research, various protected areas and protected habitat types across Europe are predicted to be negatively affected by climatic change (Normand et al. 2007). Changes in climatic conditions will likely threaten the

\footnotetext{
A. Sârbu ( $\square)$

Department of Botany and Microbiology, University of Bucharest, Aleea Portocalelor 1-3, Sector 5, 060101 Bucureşti, Romania

e-mail: anchusa24@yahoo.com

G. Janauer

Department of Limnology, University of Vienna,

Althanstrasse 14, 1090 Vienna, Austria

e-mail: georg.janauer@univie.ac.at

I. Profft

Service and Competence Centre of ThüringenForst, Jaegerstrasse 1, D-99867 Gotha, Germany

e-mail: ingolf.profft@forst.thueringen.de

M. Kaligarič

Department of Biology, Faculty of Natural Sciences and Mathematics, University of Maribor, Koroška cesta 160, SI-2000 Maribor, Slovenia e-mail: mitja.kaligaric@uni-mb.si
}

\section{Doroftei}

Department of Biodiversity Conservation, Danube Delta National Institute for Research and Development, Babadag Street, No. 165, 820112 Tulcea, Romania

e-mail: doroftei@indd.tim.ro 
sustainability of existing protected plants and habitats in different ways and with different magnitude (Andrade et al. 2010). It is expected that climate change will affect the species composition, reduce the richness of taxa, and will substantially modify the functionality of many ecosystems (Andrade et al. 2010).

Some studies and projections (Araújo et al. 2011) claim that by 2080 about $58 \%$ of European terrestrial plants and vertebrate species will no longer find climatic conditions suitable for survival within the current protected areas. The consequences of potential climate change will be illustrated by Natura 2000 sites.

The aim of this chapter is to provide some information on actual and anticipated impacts of climate change responsible for potential habitat changes in Natura 2000 sites, which comprise the most important protected areas for maintaining the natural heritage of Europe (Campbell et al. 2009; EEA 2010) and especially Central Europe. This chapter was prepared as part of the international project HABITCHANGE "Adaptive management of climate induced changes of habitat diversity in protected areas," consisting of partners from protected areas and scientific organisations from eight European countries.

\subsection{Considered Habitats, Categories of Source and Taxonomic Nomenclature}

To identify the potential effects of climate change on protected habitats, Natura 2000 habitat types selected for the HABIT-CHANGE project were considered. These types were grouped into 14 categories (groups) according to the Natura 2000 system of classification (Interpretation manual of European Union Habitats, European Commission - DG EUR 27 2007). ${ }^{1}$

Three categories of sources were used to compile the information of this chapter: expert knowledge, specialised literature, and the authors' expertise.

The information on impacts per habitat group was mainly based on expert knowledge and was obtained by an enquiry of local experts focussing on actual and potential future effects of climate change on Natura 2000 habitats. The basic information was provided by experts from ten protected areas within the frame of the HABIT-CHANGE project: Balaton Upland National Park, Biebrza National Park, Danube Delta Biosphere Reserve, Flusslandschaft Elbe - Brandenburg Biosphere Reserve, Köros-Marcos National Park, Bucegi Natural Park, Rieserferner Ahrn Nature Park, Secovlje Saline Nature Park, Triglav National Park and Vessetal Thuringian Forest Biosphere Reserve.

An additional source of information was specialised literature included in HABIT-CHANGE output 3.1.1. (HABIT-CHANGE 2010) as well as the personal expertise of the authors of this chapter. The nomenclature of species used in this chapter is in accordance with The Plant List (2010).

\footnotetext{
${ }^{1}$ See HABIT-CHANGE output 3.2.5, 2011.
} 


\subsection{Impacts of Climate Change on Natura 2000 Habitats}

Out of 169 habitat types described in the EEA Natura 2000 Database of Europe, 89 corresponded with those present in the protected areas studied for the HABITCHANGE project (see Table 4.1).

Seven potential impact classes of climate change on habitats in protected areas were identified: seasonality (changes of mean and maximum temperature, precipitation, frost and snow days), hydrology (decrease of precipitation during vegetation period, change in precipitation intensity and variability), soil (change of soil structure, nutrients and chemistry), sea-level rise (local coastal flooding), extreme events (heavy rains, floods, drought, wildfire, storm), $\mathrm{CO}_{2}$ concentration (increasing concentration), and cumulative effects (the shift in species composition and abundance, the invasion of aliens, pest development, land use changes).

For coastal and halophytic habitats, the major impact of climate change can be considered sea-level rise, which induces erosion of coastlines followed by impacts on soil structure. Regarding sea-level rise, the Black Sea shows an increasing trend with an average rate of $2.11 \pm 0.2 \mathrm{~cm} /$ year (Gâştescu and Ştiucă 2008). For the Mediterranean Sea it is estimated that the sea-level will increase between 12 and $30 \mathrm{~cm}$ by 2100 (Strojan and Robic 2009).

Seacoast habitats with vulnerable halophyte vegetation could be flooded in the near future. In this context, the annual vegetation of drift lines (Natura 2000 code 1210) from the Danube Delta Biosphere Reserve, which occupies only small areas (1.968,70 ha) on marine sand deposits (Gafta and Mountford 2008) along the Black Sea shore, could be lost (Fig. 4.1).

Table 4.1 Habitat groups (classes of habitats in capital letters, subclasses of habitats in lower case letters) including the number of habitat types relevant for the HABIT-CHANGE investigation sites, listed for these groups in EEA Database of Natura 2000 sites in Europe and recorded in the investigation sites (HABIT-CHANGE 2011)

\begin{tabular}{lcc}
\hline & \multicolumn{2}{l}{ Number of habitat types } \\
\cline { 2 - 3 } Habitat group & $\begin{array}{l}\text { EEA } \\
\text { database }\end{array}$ & $\begin{array}{l}\text { HABIT-CHANGE } \\
\text { investigation areas }\end{array}$ \\
\hline 01 COASTAL AND HALOPHYTIC HABITATS & 28 & 12 \\
21 Sea dunes of the Atlantic, North Sea and Baltic coasts & 10 & 4 \\
$\quad$ (+ Black Sea) & 4 & 2 \\
23 Inland dunes, old and decalcified & 10 & 4 \\
31 Standing water & 9 & 5 \\
32 Running water & 12 & 7 \\
40 TEMPERATE HEATH AND SCRUB & 9 & 5 \\
61 Natural grasslands & 12 & 6 \\
62 Semi-natural dry grasslands and scrubland facies & 6 & 6 \\
64 Semi-natural tall-herb humid meadows & 3 & 2 \\
65 Mesophyll grasslands & 12 & 6 \\
70 RAISED BOGS AND MIRES AND FENMS & 14 & 11 \\
80 ROCKY HABITATS AND CAVES & 37 & 17 \\
91 Forests of Temperate Europe & 3 & 2 \\
94 Temperate coniferous forests & &
\end{tabular}




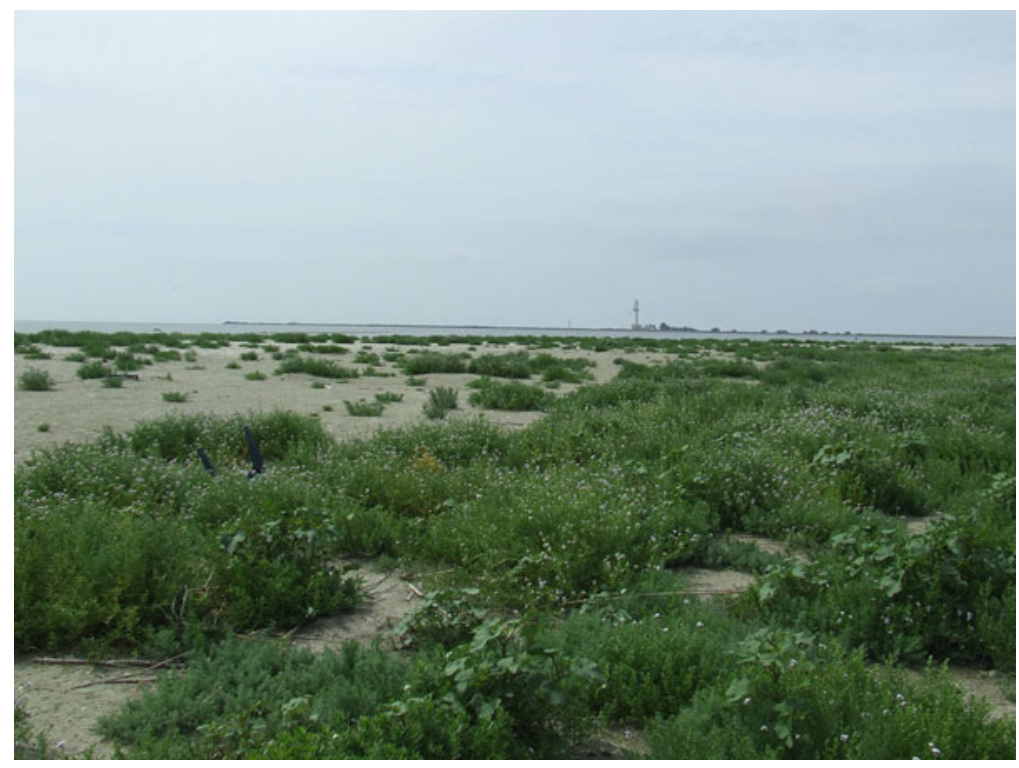

Fig. 4.1 Annual vegetation of drift lines viewed from the strictly protected area in the Danube Delta Biosphere reserve (Photo: Mihai Doroftei)

Other significant examples can be found along the Slovenian seacoast of the Mediterranean Sea (Sečovlje Salina and Škocjan Inlet) where four different coastal wetland habitat types are affected by sea-level rise: rush salt marches dominated by Juncus maritimus Lam. and/or Juncus acutus L. (Natura 2000 code: 1410) (Kaligarič and Škornik 2007), Spartina sp. Schreb. swards (Natura 2000 code: 1320), Salicornia sp. L., and other annuals colonising mud and sand (Natura 2000 code: 1310, see Fig. 4.2) and Mediterranean and thermo-Atlantic halophilic scrub (Natura 2000 code: 1420).

The main threat to these four coastal habitat types is the rising sea-level. The long-term trend of this process was $1 \mathrm{~mm}$ p.a., but in the past 25 years this trend changed to $5 \mathrm{~mm}$ p.a. (Kaligarič and Škornik 2007). Considering this development it is possible that many Mediterranean seacoast habitats will be flooded or changed in the near future. The problem is that the enlargement of coastal habitats in case of sea-level rise is impossible since they are surrounded by urban or industrial zones, agricultural areas, or infrastructure. Buffer zones for potential migration usually do not exist.

For sea dunes of the Atlantic, North Sea and Baltic coasts (plus Black Sea), the major impact of climate change will be the decline of groundwater level.

The old and decalcified inland dunes are complex habitats including pioneer communities of terophytes and lichen communities growing on barren lands (Gafta and Mountford 2008). Hydrological changes and changes of soil structure can be considered as significant impacts. 


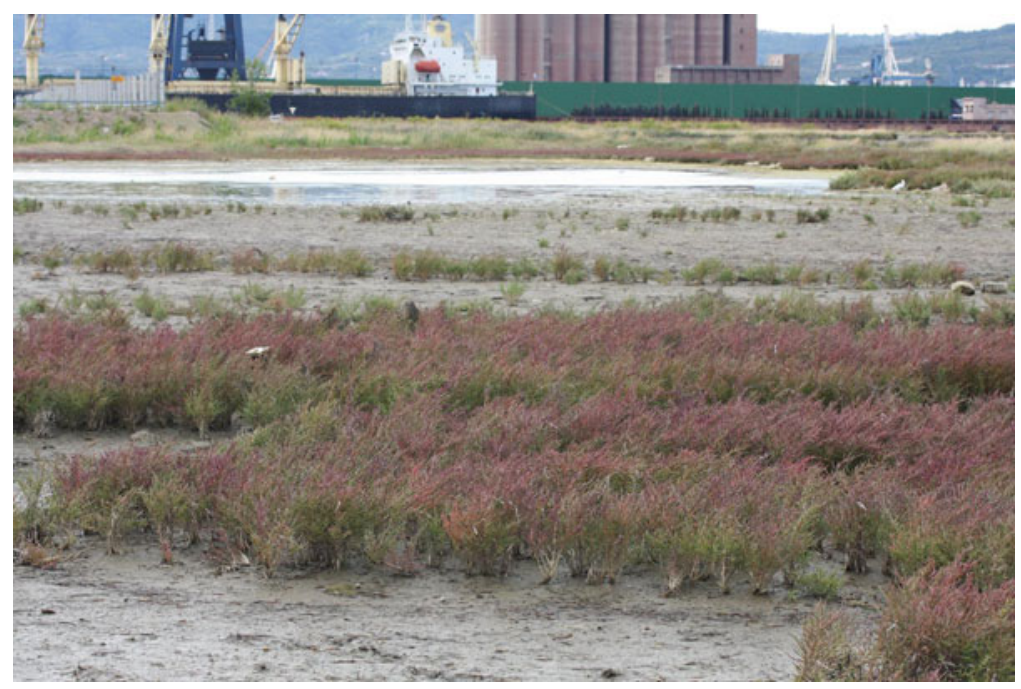

Fig. 4.2 Slovenian shallow coasts colonised with Salicornia sp. and other halophytes are frequently bordered with ports, urban areas, or infrastructure, with no possibilities to migrate in case of further sea-level rise (Photo: Mitja Kaligarič)

For standing water as well as for running water habitats, the most significant impacts are hydrological changes affecting water regime and water level.

For running waters these factors can induce an irreversible alteration of flood plain areas, river bed modification, or drying out of the river. Other relevant impacts are changes in temperature regime, which influence the development pattern of aquatic organisms and changes in bank ecotone conditions. Higher water temperature will cause water quality to deteriorate with a negative effect on microorganisms, benthic invertebrate, plankton species, and for different categories of aquatic macrophytes (Campbell et al. 2009).

The majority of aquatic macrophytes in the Lower Danube river system belongs to the mesothermophyte group (Elodea canadensis Michx., Ceratophyllum demersum L., Potamogeton crispus L., P. nodosus Poir., P. pectinatus L., Vallisneria spiralis L. s.o.) (Popescu and Sanda 1998). In contrast some adventive aquatic macrophytes as Elodea nuttallii (Planch.) H.St. John (Fig. 4.3) and Lemna minuta Kunth (Fig. 4.4) prefer warmer water temperatures and can develop an invasive behaviour in conditions of climate change. In this respect Elodea nuttallii, a short-time adventive species in Romania (Ciocârlan et al. 1998) was found in the majority of the Romanian Danube river corridors 8 years after its first discovery (Sârbu et al. 2006). Lemna minuta was first discovered in Romania within the Danube Delta in 2011 (Ciocârlan 2011).

As cumulative effects changes regarding the structure of aquatic biocoenosis and the expansion of alien species, especially more thermophylic organisms, must be expected. 


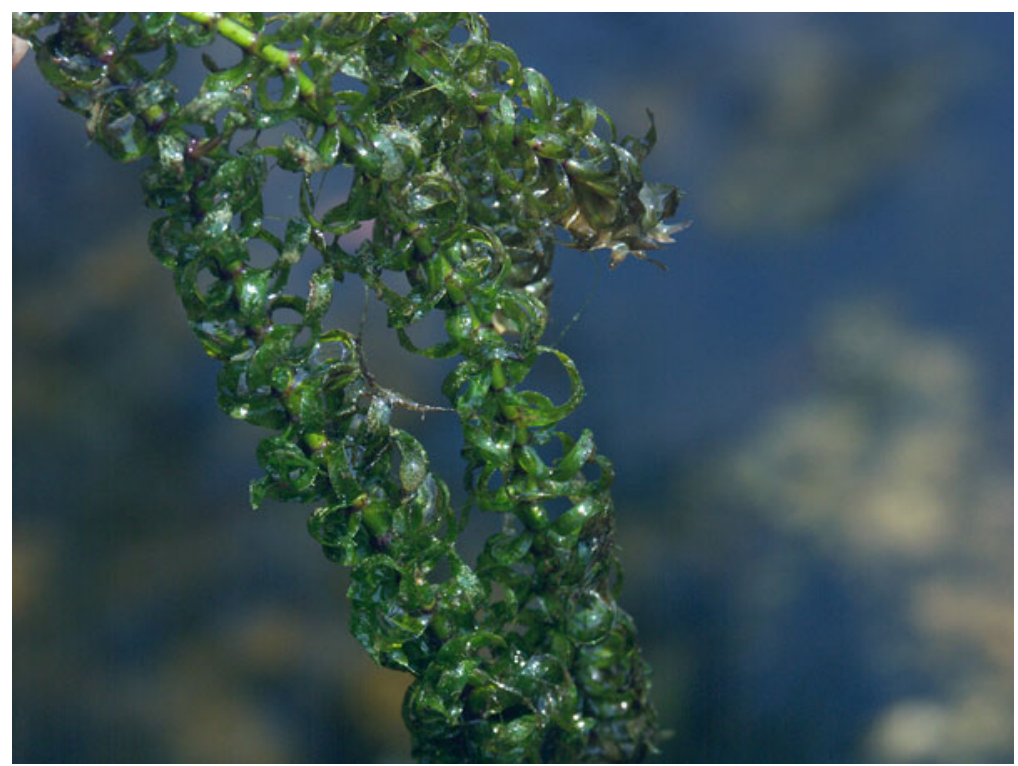

Fig. 4.3 Elodea nuttallii, Danube Delta Biosphere reserve, June 2005 (Photo: Anca Sârbu)

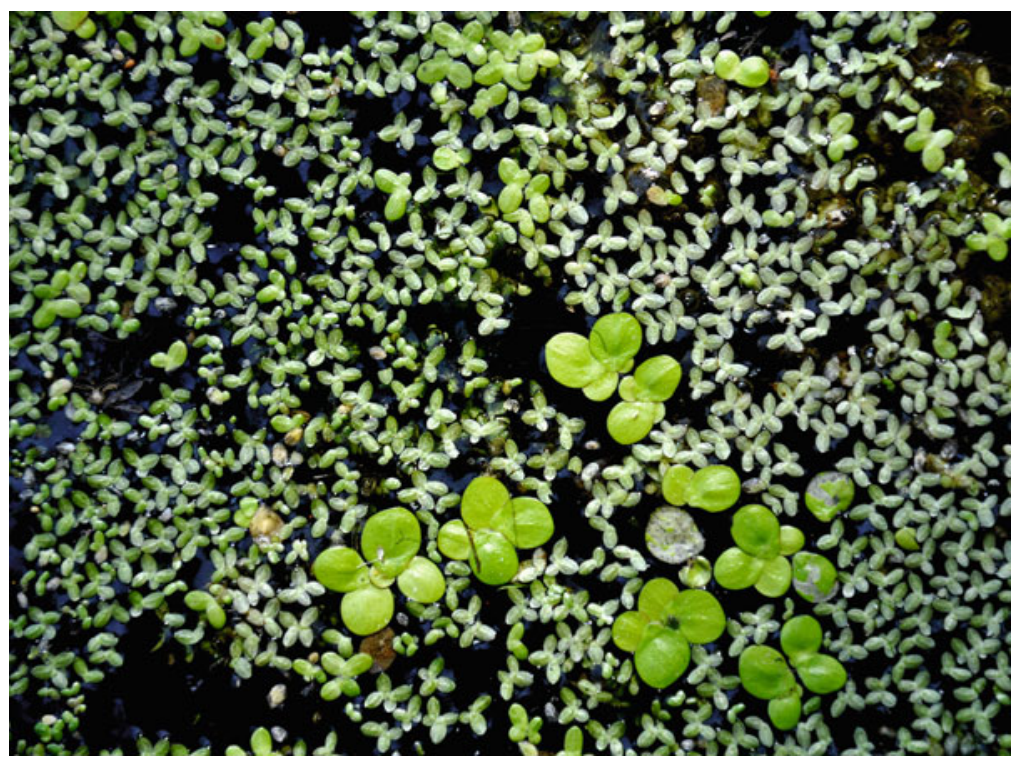

Fig. 4.4 Lemna minuta (the small one) and Lemna gibba L., Kis-Balaton area, Hungary (Photo: Marco Neubert) 


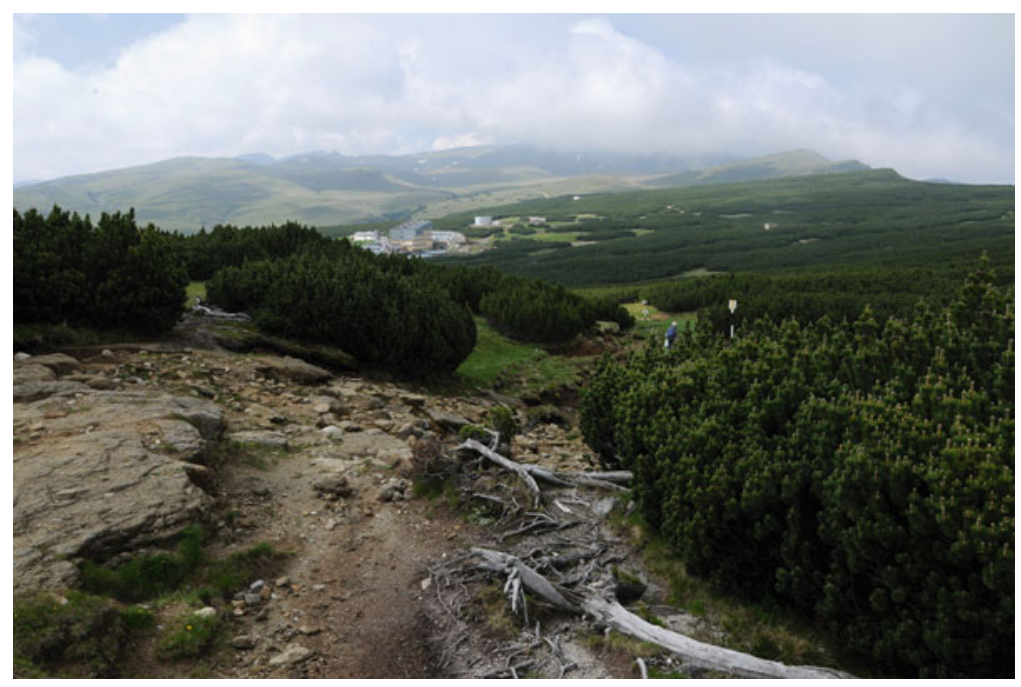

Fig. 4.5 Bushes with Pinus mugo and Rhododendron myrtifolium at the Bucegi mountains affected by erosion and fragmentation (Photo: Anca Sârbu)

Significant impacts with periodic variations are expected for temperate heaths and scrubs in alpine climate. Changes will occur in the temperature and precipitation regime, frost and snow days. Also, extreme events like torrents and storms associated with erosion, ruptures, and habitat fragmentation will occur more often. The expected cumulative effect could lead to the potential loss of plant species strongly depending on humidity and low temperature, as well as to degradation and potential loss of some types of habitats dominated by mesophytes or mesohygrophytes and psichrothermophytes, like bushlands with Pinus mugo Turra and Rhododendron myrtifolium Schott \& Kotschy (Natura 2000 code: 4070, Fig. 4.5).

An assessment of this habitat type carried out in June and July 2010 at Bucegi mountain shows that $90 \%$ of the recorded plant species are depending on humidity (mesophytes and mesohygrophytes) and $70 \%$ on low temperature (hekistotermophytes, psichrotermophytes and microthermophytes).

Climate changes expressed in terms of temperature rise and humidity decrease affect the dominant species (Pinus mugo), significantly reduce its diversity, and endanger the quality and integrity of this habitat type. Erosion and human activities, such as tourism, construction works, transportation, or eutrophication are all factors intensifying this development.

Alpine natural grasslands will feel significant climate change impacts through increasing temperatures (mild winters, warm spring and summer), decreasing precipitation (droughts in summers, less snow in winter), and more frequent extreme events like torrents and heavy rains associated with soil erosion. It is suggested that changes in composition of grasslands are likely in response to climate change (Campbell et al. 2009). Changing environmental conditions in the alpine zone will determine the disappearance of plant species sensitive to drought, 


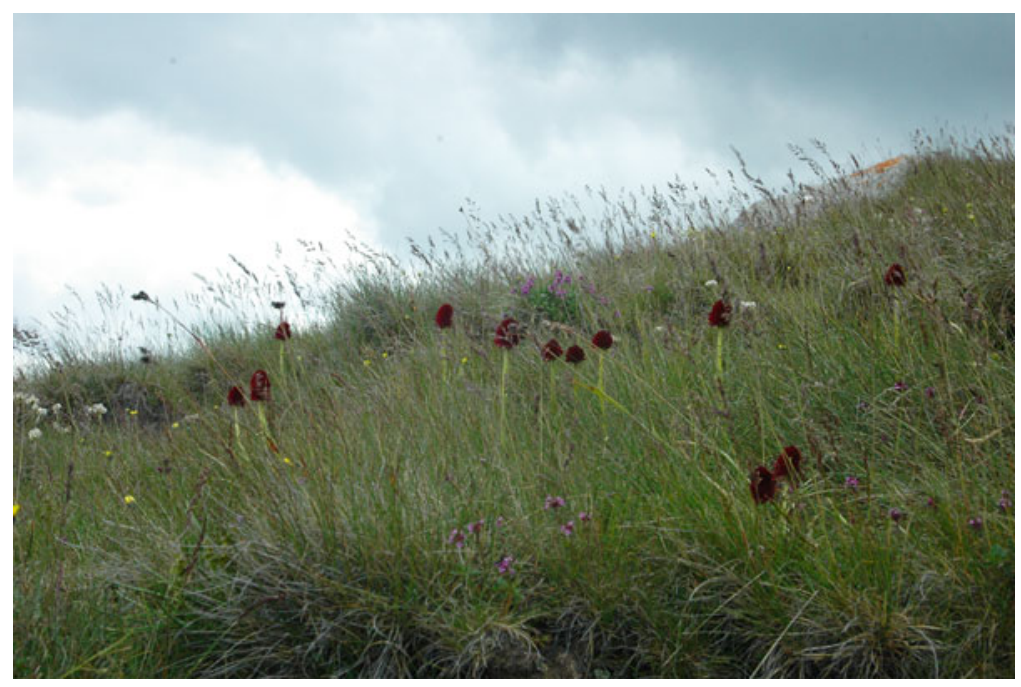

Fig. 4.6 Silicious alpine and boreal grasslands (Natura 2000 code: 6150) from Bucegi Natural Park; in front the rare and threatened plant Nigritella nigra (Photo: Anca Sârbu)

high temperature, and eutrophication, and will favour the expansion of drought tolerant ones, the increase of scrub abundance, and will modify succession sequences.

The alpine natural grasslands from Carpathian mountains, e.g. the silicious alpine and boreal grasslands (Natura 2000 code: 6150, see Fig. 4.6), accommodate many plants with high conservation value that strongly depend on low temperature, snow and humidity, such as the endemic Dianthus glacialis subsp. gelidus (Schott, Nyman \& Kotschy) Tutin and the rare Nigritella nigra (L.) Rchb. f., which can be considered threatened by changing climate conditions.

For semi-natural tall-herb humid meadows the frequency, duration, and period of flooding are significant hydrological preconditions for sustenance. Severe drought and increasing mean temperature interfere with this necessary environmental setting and are often associated with a significant frequency of wildfires. Other effects like mineralisation of peat and accumulation of organic material address impacts on soil structure and nutrients.

For mesophyll grasslands (see Fig. 4.7) significant impacts are related to hydrology, e.g. changes in flooding regime and of groundwater level, rising temperature, change in precipitation pattern, or extreme weather events like heavy rains associated with soil erosion. Cumulative effects consist of changes in succession sequences, expansion of alien species, degradation of the habitat, and possible loss of species with high conservation value like the endangered plant Gentiana lutea L., and the rare plant Trollius europaeus $\mathrm{L}$.

For raised bogs, mires and fens many different impacts can be considered: changes of groundwater level, changes of precipitation pattern, temperature 
Fig. 4.7 Mountain hay meadows (Natura 2000 code: 6520) with a significant population of the rare plant Trollius europaeus L. within Bucegi Natural Park (Photo: Anca Sârbu)

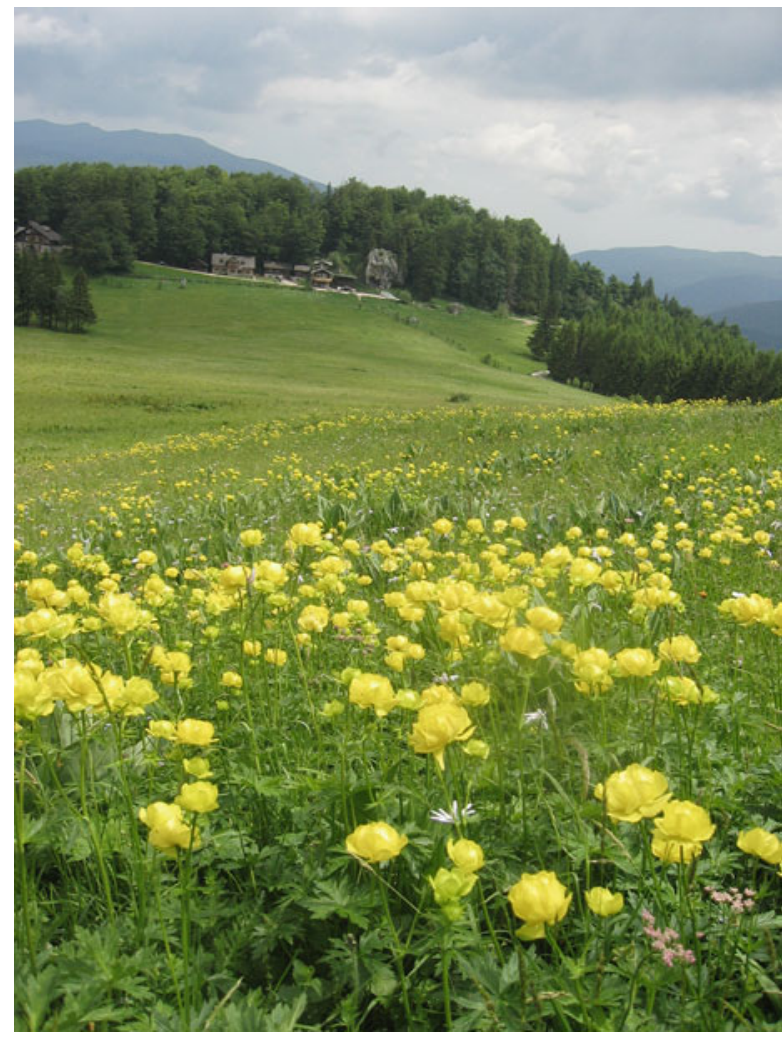

increase and drought, wildfires, or changes in soil quality, such erosion, soil leaching, mineralisation of peat, and accumulation of organic material. Cumulative effects can consist of changes in succession sequences, increasing tree cover and spread of reed and alien plants, which affects bryophytes and other specialised plants.

For rocky habitats and caves (Fig. 4.8) significant impacts are related to temperature increases and precipitation decreases associated with permafrost melting and glacier retreat. Soil erosion and the frequency of avalanches as extreme events also need to be considered. Among cumulative impacts the loss of the colder climatic zone at high altitudes and a significant loss of plant species strongly depending on vernalisation can be expected.

In this respect many plants found within Natura 2000 habitat type 8210 at Bucegi Natural Park like the endemic Achillea oxyloba subsp. schurii (Sch.Bip.), Heimerl, and the rare plants Androsace chamaejasme Wulfen, Asplenium adulterinum Milde, Campanula carpatica Jacq. Saxifraga oppositifolia L., and Viola dacica Borbás s.o can be considered under threat (Ciocârlan 2009).

Forest of temperate Europe vegetation type will experience seasonal hydrological impacts on soils and related extreme events. Trees are especially negatively 
Fig. 4.8 Calcareous rocky slopes with chasmophytic vegetation (Natura 2000 code: 8210) with Achillea oxyloba subsps. schurii within Bucegi Natural Park (Photo: Anca Sârbu)

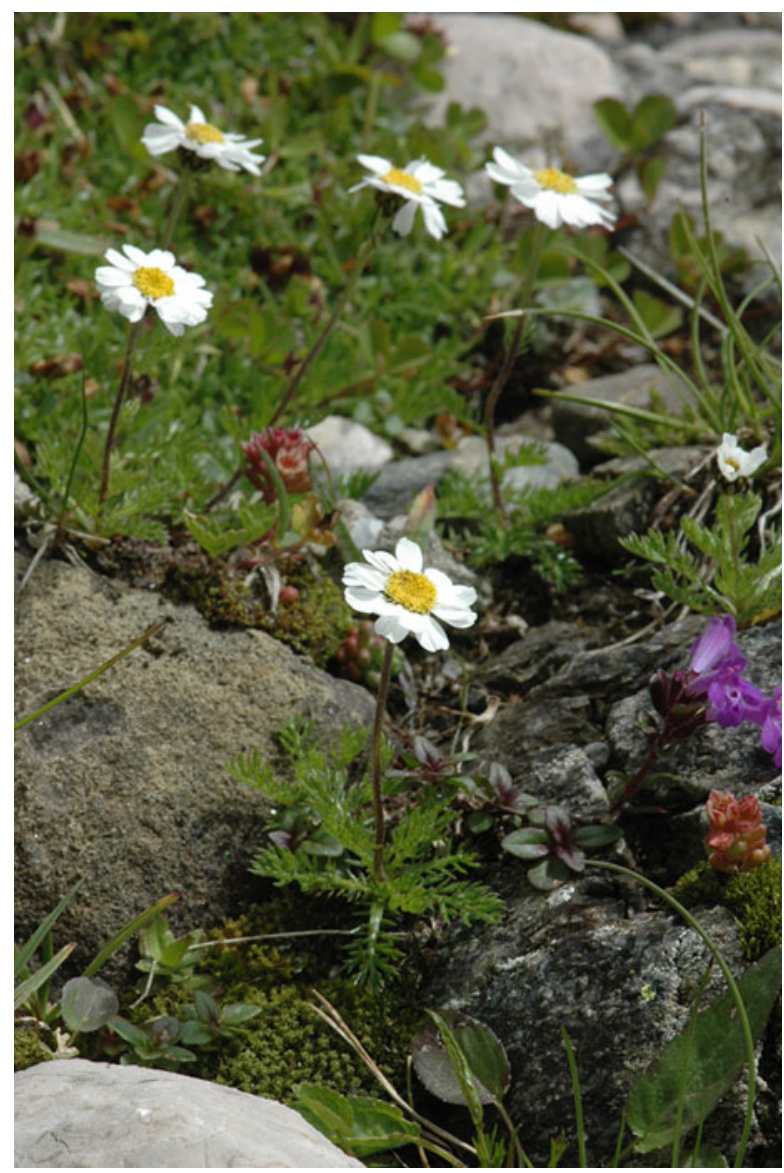

affected by changes in seasonality (Milad et al. 2011; Profft and Frischbier 2009), temperature increase, and changes in precipitation pattern. They are also sensitive to increased drought stress associated with fluctuation in frequency, amplitude and moment of a drought's appearance, and to changes in groundwater level and in flooding regime. Torrents, storms, and heavy rains can all be ranked as heavy impacts. Cumulative impacts could lead to the loss of relevant and sensitive species, changes in the structure of the forest community, drying out of forest areas, an increased advantage of the propagation of pests, and improved conditions for the development of alien plants. Monitoring data show a significant relation between warmer growing conditions and the distribution and abundance of pest insects, such as bark beetles on spruce or larch (e.g. Ips typographus Linné), as well as oak processionary (Thaumetopoea processionea Linné) or horse chestnut leaf miner (Cameraria ohridella Deschka and Dimic).

Temperate coniferous forests dominated by trees depending on water supply (mesophytes, mesohygrophytes) and low temperatures (microthermophytes) are 


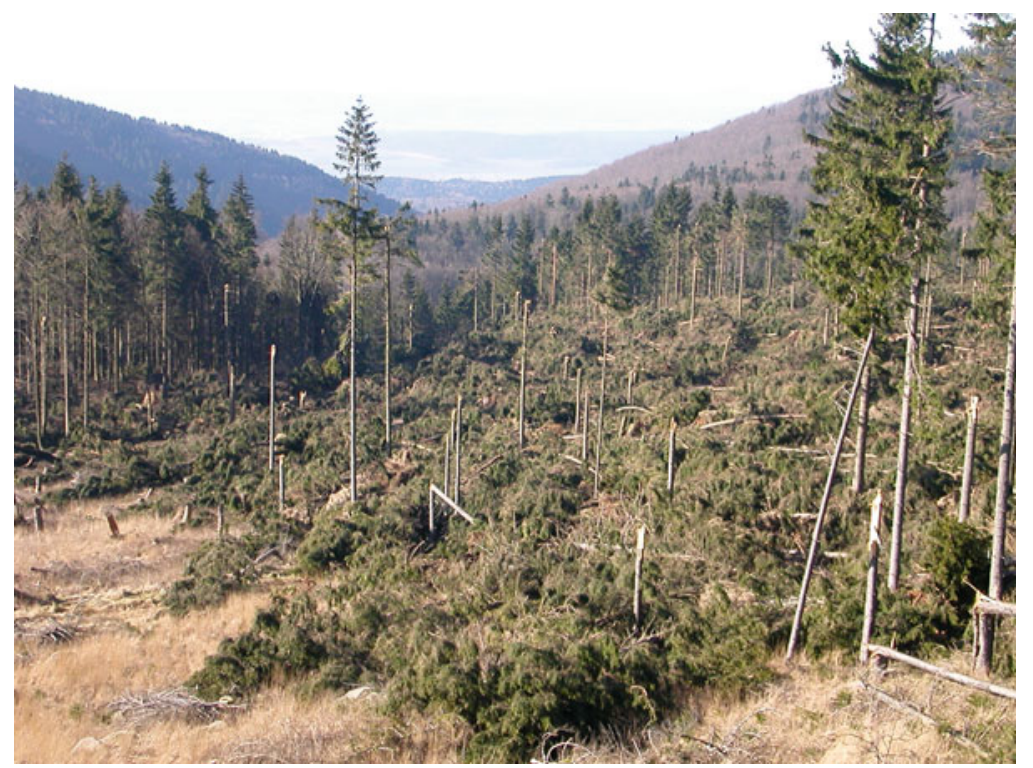

Fig. 4.9 Spruce forest ecosystem of the Thuringian Forest, Germany, damaged by storm "Kyrill" on January 17, 2007. In total, about $2.7 \%$ of the forest area was damaged. According to the German Weather Service (Deutscher Wetterdienst, DWD), the likelihood of the occurrence of such an extreme weather event is every 10-20 years (Photo: Karina Kahlert)

affected by changes in temperature and precipitation pattern as well as in groundwater level. Heavy rains, storms, and torrents need to be considered as significant impacts for forest life as well. They can have a great impact on stand stability and can cause sudden and dramatic ecological and economic losses (Fig. 4.9).

Some tree species might benefit from warmer growing conditions and longer vegetation period, but if the speed of increasing temperature is higher than the natural drifting speed for tree species (Bolte et al. 2009) the growing potential of some trees, e.g. Picea abies L., will be affected. Decreasing precipitation during the growing season is predicted for many parts of Europe (IPCC 2007) by various climate scenarios. This could diminish growing conditions for present tree species, too (Fig. 4.10).

\subsection{Which Trends Can Be Predicted for Natura 2000 Habitats?}

Climate change impacts on ecosystems and species living within these add more and more to the global challenge of biodiversity conservation (Campbell et al. 2009; Pompe et al. 2010).

In this respect the Intergovernmental Panel on Climate Change (IPCC 2007) has pointed out several types of major changes to ecosystems as a result of climate 


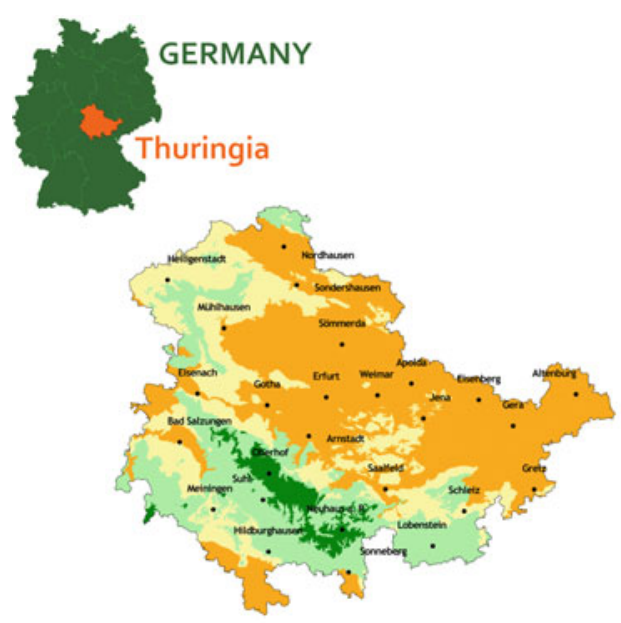

1971-2000
High growing potential for Spruce Moderate growing potential for Spruce Moderate risk potential for Spruce High risk potential for Spruce

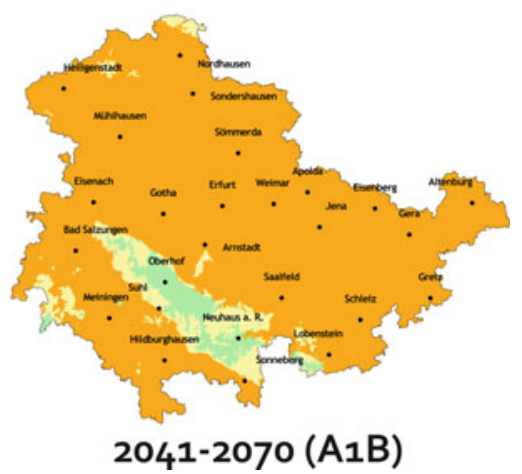

Fig. 4.10 Assessment of present and future growing potential for Norway Spruce (Picea abies L.) according to a combination of four climate thresholds for Spruce (Source: ThüringenForst, Service and Competence Centre)

change: changes in the distribution, composition, structure and functions, as well as changes in successional processes and in the value and services they provide.

There is also increasing evidence for ecological responses to recent climate changes and for the need of more information concerning the different possible climate change impacts and the linkages between them (Walther 2007).

Based on the climate change effects reported from the ten protected investigation areas of the HABIT-CHANGE project, seven impact classes related to 14 habitat groups were identified: seasonality, hydrology, soil, sea-level rise, extreme events, $\mathrm{CO}_{2}$ concentration, and cumulative effects.

The 14 groups of Natura 2000 habitats taken into consideration in this chapter are simultaneously subjected to various categories of climate change impacts. All of them are being affected to different degrees by cumulative effects of climate change.

It is quite difficult to estimate which of these groups of habitats will be more profoundly affected by climate change impact in the future. The magnitude of impacts varies depending on the ecological requirements of plant species, in combination with their distribution range and dispersal ability (Normand et al. 2007).

However, some assertions can be made. The extent and rate of climate change puts forest ecosystems at high risk. Forestry in general faces particular difficulties, such as strong dependency on existing site conditions that cannot be modified, existing stand conditions exposed to nitrogen deposition and acidification, and multiple demands and expectations by society that have a direct influence on management strategies. A positive effect on forest growths can be expected on the short- and medium-term due to changes in mean climatic variables, but on the long term increasing drought and extreme weather events will become great risk factors for forest sustainability (Lindner et al. 2010). 
A series of evaluations on the ecological spectrum of sub-alpine and alpine habitats of Bucegi mountains, made within the HABIT-CHANGE project, support the fact that they show significant vulnerability (related to $50-70 \%$ of the species) with regards to projected temperature and humidity changes. If we add the fact that alpine plants may only be able to migrate horizontally (and this is by no means a certainty) we can conclude that alpine habitats are also very vulnerable. In this respect some studies addressed to alpine grasslands, underline the acute vulnerability of many dominant grasses and rare species to warming and drought and predict significant shifts in plant composition (Erschbamer et al. 2009).

Taking into account the inevitable prognosis of rising sea-levels, we can conclude that halophyte and coastal habitats may be lost in the near future. Such habitat types are more often near urban, industrial, or tourist areas, which diminish the chance even more that they could avoid effects of sea-level rise by migrating into other areas. The sustainability of coastal habitats will be especially problematic where there are limited options for landward migration (Gilman et al. 2008; Strojan and Robic 2009). Coastal habitats and their species that are of community interest are at risk in Europe and many of them have an unfavourable conservation status (EEA 2010).

Unfortunately, climate change effects will become noticeable everywhere and the vegetation, the basis on which biodiversity is established, will react according to the vital requirements of species it is composed of. This reaction to projected climate change impacts will be at a slower or faster rate, but nonetheless vegetation will react in a non-favourable direction.

In this respect some effects which also address Natura 2000 habitats were already observed (Campbell et al. 2009) and are expected to increase: the shifts in location of those ecosystems that can migrate (Salazar et al. 2007), changes in species composition and richness (Moritz et al. 2008), the loss of plant species with small ranges (Pompe et al. 2008) or strongly depending on special edaphic conditions (Colwell et al. 2008), the spread of invasive species (Rahel and Olden 2008), or the opportunity for native species to become invasive (van der Wal et al. 2008).

Climate change is already affecting ecosystems and the species of Natura 2000 sites. The understanding and documentation of this ongoing process will become increasingly important for the development of adaptation in the conservation sector.

\subsection{Conclusions}

The results of our analysis are not representative for all Natura 2000 habitats but they give an indication on major impacts relevant for protected areas included in the HABIT-CHANGE project located in Central Europe.

The information for approximately $50 \%$ of the habitats listed in the Natura 2000 database enabled the identification of seven potential impact categories that are determined by climate change and that these habitats are confronted with now and in the future. 
Each of the 14 Natura 2000 habitat categories taken into consideration is faced with a number of climate change impacts leading to a wide variety of effects: from the reduction of biodiversity and degradation of habitat quality to the potential loss of certain habitat types strongly depending on actual climatic conditions.

Even though there are several opinions regarding the level of potential vulnerability of different habitat categories, it is difficult to pinpoint which will ultimately be more profoundly affected by climate change impacts.

A significant uncertainty still exists regarding the level of performance of Natura 2000 habitats in the future, as the multitude of plant species and of environmental parameters and their interaction make more detailed projections nearly impossible at present. Therefore, a deeper insight in the complex network of species' reaction and climate change aspects need to be made available to scientists and practitioners as to provide more focused solutions for mitigation measures and possible re-orientation of conservation practices.

Open Access This chapter is distributed under the terms of the Creative Commons Attribution Noncommercial License, which permits any noncommercial use, distribution, and reproduction in any medium, provided the original author(s) and source are credited.

\section{References}

Andrade, P. A., Herrera, F. B., \& Cazzola, G. R. (Eds.). (2010). Building resilience to climate change: Ecosystem-based adaptation and lessons from the field. Gland: IUCN.

Araújo, M. B., Alagador, D., Cabeza, M., Nogués-Bravo, D., \& Thuiller, W. (2011). Climate change threatens European conservation areas. Ecology Letters, 14(5), 484-492.

Bolte, A., Eisenhauer, D. R., \& Ehrhart, H. P. (2009). Klimawandel und Forstwirtschaft - Übereinstimmungen und Unterschiede bei der Einschätzung der Anpassungsnotwendigkeiten und Anpassungsstrategien der Bundesländer. Landbauforsch - vTI Agric For Res, 4(59), 269-278.

Campbell, A., Kapos, V., Scharlemann, J. P. W., Bubb, P., Chenery, A., Coad, L., Dickson, B., Doswald, N., Khan, M. S. I., Kershaw, F., \& Rashid, M. (2009). Review of the literature on the links between biodiversity and climate change: Impacts, adaptation and mitigation. Secretariat of the Convention on Biological Diversity, Montreal, Technical series No. 42, 124 pp.

Ciocârlan, V. (2009). Flora Ilustrată a României. Pteridophyta et Spermatophyta (3rd ed.). Bucureşti: Editura Ceres.

Ciocârlan, V. (2011). Vascular flora of the Danube Delta. Analele Stiintifice ale Universitatii "Al. I. Cuza" Iasi, Tomul LVII, fasc. 1, s. II-a. Biologie Vegetala.

Ciocârlan, V., Sârbu, I., Ştefan, N., \& Marian, T. (1998). Elodea nuttallii (Planchon) St. John a new specie in Romanian flora. Bulletin Botanical Garden, 6(1), 215-231.

Colwell, R. K., Brehm, G., Cardelus, C. L., Gilman, A. C., \& Longino, J. T. (2008). Global warming, elevational range shifts, and lowland biotic attrition in the wet tropics. Science, 322, 258-261.

EEA. (2010). The European environment - State and outlook 2010: Synthesis. Copenhagen: European Environment Agency.

Erschbamer, B., Kiebacher, T., Mallaun, M., \& Unterluggauer, P. (2009). Short-term signals of climate change along an altitudinal gradient in the South Alps. Plant Ecology, 202, 79-89.

Gafta, D., \& Mountford, O. (coord.). (2008). Manual de interpretare a habitatelor Natura 2000 din România. Cluj-Napoca: Editura Rosprint. 
Gâștescu, P., \& Ştiucă, R. (2008). Delta Dunării Rezervație a Biosferei. București: Editura CD PRESS.

Gilman, E. L., Ellison, J., Duke, N. C., \& Field, C. (2008). Threats to mangroves from climate change and adaptation options: A review. Aquatic Botany, 89, 237-250.

HABIT-CHANGE. (2010). Output 3.1.1. - Literature review, from http://www.habit-change.eu/ fileadmin/Dateisammlung/files/Outputs/HABIT-CHANGE_3_1_1_Literature_Review.pdf

HABIT-CHANGE. (2011). Output 3.2.5. - Priority matrix impacts per region and habitat 2011, from http://www.habit-change.eu/fileadmin/Dateisammlung/files/Outputs/HABITCHANGE_3_2_5_Matrix_impacts_per_habitat_2011-08-08.pdf

Interpretation manual of European Union Habitat, European Commission - DG ENVIRONMENT EUR 272007.

IPCC [Intergovernmental Panel on Climate Change]. (2007). Summary for policy makers. In M. L. Parry, O. F. Canziani, J. P. Palutikof, P. J. van der Linden, \& C. E. Hanson (Eds.), Climate change 2007: Impacts, adaptation and vulnerability. Contribution of Working Group II to the Fourth Assessment Report of the Intergovernmental Panel on Climate Change (IPCC). Cambridge: Cambridge University Press.

Kaligarič, M., \& Škornik, S. (2007). Vegetation of tall rush saltmarshes (Juncetea maritimae) and saltmarsh scrubs (Arthrocnemetea fruticosae) on the Slovenian seacoast. Annales Series Historia Naturalis, 17, 47-58.

Lindner, M., Maroschek, M., Netherer, S., Kremer, A., Barbati, A., Garcia-Gonzalo, J., Seidl, R., Delzon, S., Corona, P., Kolstro, M., Lexer, M. J., \& Marchetti, M. (2010). Climate change impacts, adaptive capacity, and vulnerability of European forest ecosystems. Forest Ecology and Management, 259, 698-709.

Milad, M., Schaich, H., Bürgi, M., \& Konold, W. (2011). Climate change and nature conservation in Central European forests: A review of consequences, concepts and challenges. Forest Ecology and Management, 261(4), 829-843.

Moritz, C., Patton, J. L., Conroy, C. J., Parra, J. L., White, G. C., \& Beissinger, S. R. (2008). Impact of a century of climate change on small-mammal communities in Yosemite National Park, USA. Science, 322, 261-264.

Normand, S., Svenning, J., \& Skov, F. (2007). National and European perspectives on climate change sensitivity of the habitats directive characteristics plant species. Journal for Nature Conservation, 15(1), 41-53.

Pompe, S., Hanspach, J., Badeck, F., Klotz, S., Thuiller, W., \& Kuhn, I. (2008). Climate and land use change impacts on plant distributions in Germany. Biology Letters, 4, 564-567.

Pompe, S., Hanspach, J., Badeck, F.-W., Klotz, S., Bruelheide, H., \& Kühn, I. (2010). Investigating habitat-specific plant species pools under climate change. Basic and Applied Ecology, 11 (7), 603-611.

Popescu, A., \& Sanda, V. (1998). Conspectul florei cormofitelor spontane din România. Acta Botanica Horti Bucurestiensis, /1998/, 3-336.

Profft, I., \& Frischbier, N. (2009). Forestry in a changing climate - the necessity of thinking decades ahead. In F. Feldmann, D. V. Alfors, \& C. Furk (Eds.), Crop plant resistance to biotic and abiotic factors (pp. 66-73). Braunschweig: Deutsche Phytometrische Gesellschaft.

Rahel, F. L., \& Olden, J. D. (2008). Assessing the effects of climate change on aquatic invasive species. Conservation Biology, 22, 521-533.

Salazar, L. F., Nobre, C. A., \& Oyama, M. D. (2007). Climate change consequences on the biome distribution in tropical South America. Geophysical Research Letters, 34, L09708.

Sârbu, A., Samarandache, D., Janauer, G., \& Pascale, G. (2006). Elodea nuttallii (Planchon) St. John - a competitive hydrophyte in the Romanian Danube river corridors. Program \& Book of Abstracts. 36th International Conference International Association for Danube Research. 4-8 Sept 2006, Klosternenburg \& Vienna.

Stern, N. (2007). The economics of climate change. The stern review. Cambridge: Cambridge University Press. 
Strojan, I., \& Robic, M. (2009). Environmental indicators in Slovenia, sea level. [Slovenian] from: http://kazalci.arso.gov.si/?anddata $=$ indicatorandihd_id=146andmenu_group_id $=10$.

The Plant List. (2010). Version 1. [Online]. Retrieved June 27, 2012, from http://www.the plantlist.org/.

van der Wal, R., Truscott, A. M., Pearce, I. S. K., Cole, L., Harris, M. P., \& Wanless, S. (2008). Multiple anthropogenic changes cause biodiversity loss through plant invasion. Global Change Biology, 14, 1428-1436.

Walther, G. R. (2007). Ecology: Tackling ecological complexity in climate impact research. Science, 315(5812), 606-607. 